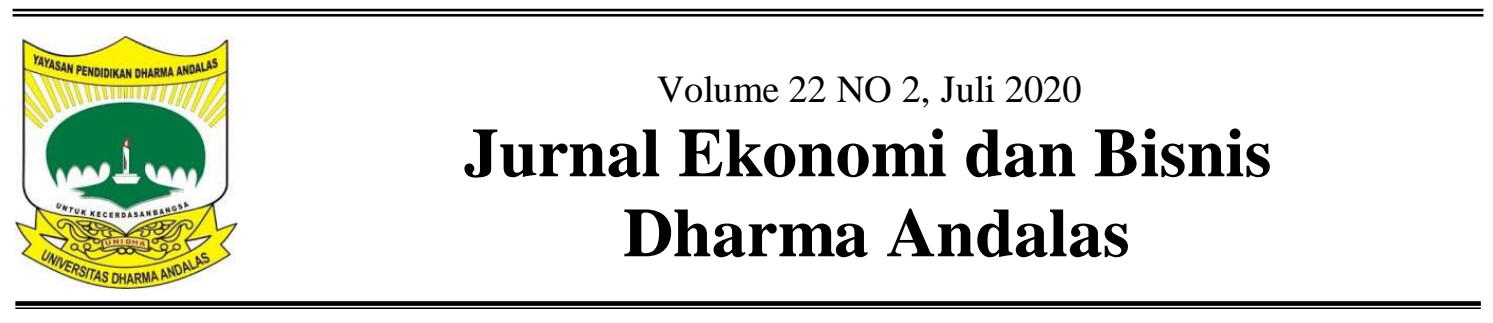

\title{
Pengaruh Pengelolaan Keuangan Daerah dan Sistem Akuntansi Keuangan Daerah Terhadap Kinerja Pemerintahan Daerah (Studi kasus pada BPKAD di Kota Padang)
}

\author{
Dewi Sartika $^{1}$, Deby Clara Monita ${ }^{2}$, Andre Ilyas ${ }^{3}$ \\ Fakultas Ekonomi dan Bisnis, Universitas Dharma Andalas ${ }^{1,2}$ \\ Universitas Putra Indonesia "YPTK" Padang 3 \\ email:dsartika959@yahoo.com ${ }^{1}$ \\ debyclaramonita28@gmail.com ${ }^{2}$
}

\begin{abstract}
This study aims to determine the Effect of Regional Financial Management and Regional Financial Accounting Systems on Regional Government Performance. The researcher examined several variables that allegedly influenced the performance of regional government namely financial management and financial accounting systems.

This research uses causal research, with qualitative and quantitative methods. The unit of analysis in this study is the Regional Financial and Asset Management Agency (BPKAD) of the City of Padang. The population in this study were 83 employees using the survey method. While for the technique of data collection is done by using questionnaires, interviews, documents and literature. To facilitate problem solving, this study was conducted using multiple linear regression models with the help of IBM SPSS Statistics 21.

The results of this study are that regional financial management does not have a significant effect on the performance of regional government with a significant level of 0.169 , while the regional financial accounting system has a significant influence on the performance of local governments with a significant level of 0.000. Regional financial management and regional financial accounting systems have a significant influence on local government performance of $25.6 \%$ while the remainder is explained by other factors.
\end{abstract}

Keywords: regional financial management, regional financial accounting systems and local government performance

\begin{abstract}
ABSTRAK
Penelitian ini bertujuan untuk mengetahui Pengaruh Pengelolaan Keuangan Daerah dan Sistem Akuntansi Keuangan Daerah Terhadap Kinerja Pemerintahan Daerah.Peneliti menguji beberapa variabel yang diduga mempengaruhi kinerja pemerintahan daerah yaitu pengelolaan keuangan dan sistem akuntansi keuangan.

Penelitian ini menggunakan jenis penelitian kausual, dengan metode kualitatif dan kuantitatif. Unit analisis dalam penelitian ini adalah Badan Pengelolaan Keuangan dan Aset Daerah (BPKAD) Kota Padang. Populasi pada penelitian ini sebanyak 83 pegawai dengan menggunakan metodesurvey. Sedangkan untuk teknik pengumpulan data dilakukan dengan menggunakan kuesioner, wawancara, dokumen dan kepustakaan. Untuk memudahkan pemecahan masalah, penelitian ini dilakukan menggunakan model regresi linier berganda dengan bantuan IBM SPSS Statistics 21.
\end{abstract}


Hasil penelitian ini adalah pengelolaan keuangan daerah tidak mempunyai pengaruh signifikan terhadap kinerja pemerintahan daerah dengan taraf signifikan 0.169, sedangkan sistem akuntansi keuangan daerah mempunyai pengaruh signifikan terhadap kinerja pemerintah daerah dengan taraf signifikan 0.000. Pengelolaan keuangan daerah dan sistem akuntansi keuangan daerah mempunyai pengaruh signifikan terhadap kinerja pemertintah daerah sebesar $25.6 \%$ sedangkan sisanya dijelaskan oleh faktor-faktor yang lain.

Kata Kunci: pengelolaan keuangan daerah, sistem akuntansi keuangan daerah dan kinerja pemerintah daerah.

\section{PENDAHULUAN}

Pemerintah daerah telah diberikan kewenangan dalam mengurus sendiri urusan pemerintahannya, hal ini telah diatur dalam otonomi daerah berdasarkan undang-undang yang berlaku. Otonomi daerah merupakan bagian penyelenggaraan pemerintah dalam upaya untuk mempercepat terwujudnya kesejahteraan masyarakat melalui peningkatan pelayanan, peran serta masyarakat, pemberdayaan daerah dalam pengambilan keputusan daerah.

Penyelenggaraan pemerintah yang baik adalah suatu bentuk keberhasilan dalam menjalankan tugas untuk membangun negara sesuai dengan tujuan yang telah direncanakan. Menurut Halim (2007) dalam Hidayat (2015) pada saat ini pemerintah daerah dihadapkan oleh banyaknya tuntutan baik dari segi internal yaitu peningkatan kinerja yang optimal dan segi eksternal yaitu keinginan masyarakat agar pemerintah daerah dapat mewujudkan tujuan masyarakat daerah yang sejahtera sebagai suatu keterlibatan dari penerapan otonomi daerah yang mengutamakan akuntabilitas kinerja dan peningkatan pelayanan publik.

Kinerja merupakan salah satu kunci bagi suatu organisasi perusahaan, pemerintah, dan perguruan tinggi. Kinerja juga termasukdalam aspek sosial ekonomi kemasyarakatan, karena banyak organisasi

yang memasukkan kata kinerja didalam visi misinya. Pencapaian kinerja tidak hanya diharapkan pada karyawan saja melainkan dalam jangka panjang diharapkan mampu meningkatkan kinerja kelembagaan (Rosmawati, 2011).

Kinerja memang telah menjadi sorotan penting dalam seluruh tahapan penyelenggaraan baik di pemerintah pusat maupun dipemerintah daerah. Menurut Halidayati (2014) Kinerja pemerintah saat ini sering dinilai tidak produktif, tidak efisien, rendah kualitas, miskin inovasi dan kreativitas. Dalam hal evaluasi kinerja saja hingga saat ini belum tersedia payung hukum yang menjadi dasar dan pedoman penyusunan dokumen evaluasi kinerja pemerintah daerah. Selain itu kurangnya jumlah dan kualitas pengelolaan kebijakan pemerintah daerah adalah salah satu penyebab kurang berkualitasnya produk kebijakan yang dihasilkan, sehingga peningkatan pelayanan dan kesejahteraan kepada masyarakat sebagai salah satu visi/misi dan tujuan pemerintah daerah akan sulit tercapai.

Menurut Mahsun (2013:25)

"Kinerja adalah Gambaran mengenai tingkat pencapaian pelaksanaan suatu kegiatan/program/kebijakan dalam mewujudkan sasaran, tujuan, misi dan visi organisasi yang tertuang dalam strategi perencanaan suatu organisasi".

Selama ini keberhasilan maupun kegagalan dari kinerja pemerintah daerah dalam menjalankan tugas pokok dan fungsinya sulit untuk dilakukan secara objektif. Untuk meningkatkan kinerja pemerintahan terdapat beberapa faktor yang mempengaruhi tingkat keberhasilan suatu organisasi. Faktor pertama yang mempengaruhi ialah pengelolaan keuangan daerah. Menurut Abdul (2009) dalam penelitiannya 
menyatakan bahwa, kinerja pemerintah daerah dipengaruhi oleh pengelolaan keuangan daerah.

Pengelolaan keuangan daerah yang baik berorientasi pada kinerja menunjukkan adanya akuntabilitas kinerja yang terdapat keterkaitan antara sasaran strategis yang ingin dicapai dengan jumlah dana yang dialokasikan maka dapat diasumsikan bahwa pengelolaan keuangan yang baik mempunyai pengaruh terhadap kinerja suatu instansi atau organisasi. Pengelolaan keuangan yang baik akan menciptakan laporan keuangan yang baik pula, hal ini dapat mengindikasikan kinerja yang baik pula pada suatu instansi atau organisasi.

Pengelolaan keuangan daerah harus transparansi yang mulai dari proses perencanaan, penyusunan, dan pelaksanaan anggaran daerah. Selain itu, akuntabilitas dalam pertanggungjawaban publik juga diperlukan, dalam arti bahwa proses penganggaran mulai dari perencanaan, penyusunan, dan pelaksanaan harus benar-benar dapat dilaporkan dan dipertanggungjawabkan ke pada DPRD dan masyarakat. Kemudian diterapkan prinsip value for money yang berarti terdapat tiga prinsip dalam proses penganggaran yaitu ekonomi, efisiensi dan efektivitas.

Dilihat disisi lain tuntutan transparansi dan akuntabilitas dalam sistem pemerintah semakin meningkat pada era reformasi saat ini, termasuk transparansi dalam pengelolaan keuangan Pemerintah daerah. Pemerintah Daerah diwajibkan menyusun laporan pertanggungjawaban yang menggunakan sistem akuntansi yang diatur oleh pemerintah pusat dalam bentuk Undang-Undang dan Peraturan Pemerintah yang bersifat mengikat seluruh Pemerintah Daerah yang merupakan wujud dari Pengelolaan Keuangan Daerah. Tidak hanya pengelolaan keuangan daerah, sistem akuntansi keuangan juga terus berubah, hal ini dengan diterbitkannya SAP tahun 2010 yaitu sistem akuntansi daerah dilaksanakan oleh pejabat pengelola keuangan daerah (PPKD) pada satuan kerja pengelolaan keuangan daerah (SKPKD) dan sistem akuntansi satuan kerja perangkat daerah (SKPD) dilaksanakan oleh pejabat penatausahaan keuangan (PPK)-SKPD.

$\begin{array}{ccr}\text { Faktor lain yang turut } \\ \text { menentukan } & \text { kesuksesan dan }\end{array}$ mempengaruhi kinerja pemerintahan adalah sistem akuntansi keuangan daerah. Menurut Mardiasmo (2004) dalam Almanda (2013) menerangkan bahwa kinerja pemerintah daerah akan tercapai dengan dilaksanakannya sistem akuntansi keuangan daerah yang secara parsial berpengaruh signifikan terhadap kinerja pemerintah daerah yang dapat menimbulkan dukungan yang kuat terhadap kinerja pemerintah daerah yang dicapai.

Sistem akuntansi keuangan daerah merupakan bagian dari akuntansi sektor publik yang mencatat dan melaporkan semua transaksi yang berkaitan dengan keuangan. Keuangan daerah adalah yang dapat dinilai dengan uang termasuk kekayaan yang berhubungan dengan hak dan kewajiban daerah dalam rangka menyelenggarakan pemerintah daerah yang baik. Sistem akuntansi keuangan daerah dapat mendukung untuk pencapaian kinerja, penilaian pemerintah yang baik dilihat dari pencapaian kinerja pemerintah itu sendiri (Hidayat, 2015).

Sistem akuntansi keuangan daerah adalah serangkaian prosedur mulai dari proses pengumpulan data, pencatatan, penggolongan dan peringkasan atas transaksi dan/atau kejadian keuangan serta pelaporan keuangan dalam rangka pertanggungjawaban pelaksanaan APBD yang dapat dilakukan secara manual atau menggunakan aplikasi komputer. Sejalan 
dengan pelaksanaan Otonomi Daerah, diperlukan sistem pengelolaan keuangan daerah yang baik dalam rangka mengelola dana dengan sistem desentralisasi secara transparan, efisien, efektif, dan dapat dipertanggungjawabkan kepada masyarakat luas. Untuk mewujudkan hal tersebut diperlukan suatu pemikiran yang cerdas melalui inovasi sistem akuntansi. (Halim, 2012:40).

Menurut hasil wawancara awal dengan Medry Adrian bagian program, ia menyatakan bahwa masalah yang terjadi saat ini, kinerja pemerintahan daerah pada Badan pengelolaan Keuangan dan Aset Daerah (BPKAD) Kota Padang dianggap tidak efektif karena pencapaian yang diinginkan kadang tidak sesuai dengan rencana dan waktu yang telah ditetapkan. Disebabkan terjadinya masalah gangguan jaringan karena cuaca dan gangguan terlambatnya pelaporan karena salah input oleh operator SKPD. Dilihat dari segi aplikasi banyaknya operator yang belum mengetahui tentang aplikasi karena setiap tahunnya sering terjadi pergantian operator.

Kasus yang pernah terjadi mengenai kinerja pemerintah kota padang ialah peningkatan Kinerja Penyelenggaraan Pemerintah Daerah (KPPD) dikeluarkan oleh kementrian dalam negeri (Kemendagri) melalui surat keputusan Mendagri Gamawan Fauzi. Sedangkan keputusan mendagri tentang KPPD 2013 ditekan oleh mendagri Tjahjo Kumolo, tertanggal 14 desember 2014. Tahun 2010 peringkat KPPD Sumbar nomor 9 nasional dan di wilayah Sumatera peringkat 8 dengan skor 2,0436. Saat itu di wilayah Sumatera, hanya peringkat KPPD Bengkulu dan Aceh yang berada dibawah Sumbar. Sedangkan 7 KPPD provinsi lainnya berada di atas Sumbar.

Pada tahun 2012 peringkat KPPD Sumbar mengalami peningkatan, yakni ke nomor 10 nasional dan di wilayah Sumatera peringkat 2 dengan skor 2,4162. Saat ini di wilayah Sumatera hanya peringkat KPPD kepulauan Riau (Kepri) yang berada di atas Sumbar pada peringkat 5. Sedangkan 8 KPPD provinsi lainnya berada di bawah Sumbar. Ditahun 2013, KPPD Sumbar melorot ke posisi 20 nasional dan di wilayah Sumatera peringkat 8 denga skor 2,2352. Saat ini di wilayah Sumatera, hanya peringkat KPPD Bengkulu dan Riau yang berada di bawah Sumbar. Sedangkan 7 KPPD provinsi lainnya berada di atas Sumbar. Di tahun 2013, KPPD Kepri berada di peringkat 4 nasional.

Menanggapi melorotnya KPPD Sumbar dari tahun 2012 ke tahun 2013, pamong senior Rusdi Lubis yang juga pernah menjabat sebagai Sekda Provinsi Sumbar turut prihatin. Menurutnya kondisi ini perlu menjadi perhatian bagi kepala daerah untuk segera melakukan evaluasi kinerja di pemerintahnya. Melorotnya peringkat KPPD ini tidak melulu menjadi kesalahan pemimpin, akan tetapi juga harus menjadi perhatian bagi satuan perangkat kerja daerah (SKPD) untuk meningkatkan kinerja dan komitmen. Sehingga peringkat yang saat ini memburuk ke depan bisa kembali diperbaiki

(https://www.harianhaluan.com/amp/det

ail/40212, Senin/17/12/2018, 11:40 WIB).

Dengan rendahnya penilaian laporan kinerja pemerintahan daerah akan dijadikan acuan dalam memberi rekomendasi atau penilaian dalam evaluasi LKPJ untuk tahun selajutnya, dan LKPJ akhir masa jabatan gubernur di tingkat DPRD. Gubernur, wakil gubernur, serta Sekretariat Daerah harus menyikapi ini dengan cara membangun sistem kerja yang bisa menggerakkan SKPD meningkatan kinerja. Khususnya pada Badan Pengelolaan Keuangan dan Aset Daerah (BPKAD) Kota Padang 
harus bisa membangun pengelolaan keuangan daerah dan sistem akuntansi keuangan daerah yang baik agar dapat mendorong kinerja pemerintahan daerah. Jika ini tak dilakukan, capaian kinerja pemerintah daerah di tahun selanjutnya akan bisa lebih buruk lagi.

Berdasarkan penelitian terdahulu yang berkaitan dengan penelitian ini diantaranya adalah Hidayat (2015), hasil penelitiannya yaitu pengelolaan keuangan daerah berpengaruh signifikan positif terhadap kinerja pemerintahan daerah, sistem akuntansi keuangan daerah berpengaruh signifikan positif terhadap kinerja pemerintahan daerah. Kemudian penelitian Jauharusaniah,dkk (2015), hasil penelitiannya yaitu secara parsial menunjukkan bahwa pengelolaan keuangan daerah, sistem akuntansi keuangan daerah dan partisipasi penyusunan anggaran berpengaruh terhadap kinerja pemerintahan daerah. Selanjutnya penelitian Annisa (2017), hasil penelitiannya sistem akuntansi pengelolaan keuangan daerah, pengelolaan keuangan daerah, dan good governance secara parsial berpengaruh signifikan terhadap kinerja pemerintahan daerah.

Penelitian ini merupakan replikasi dari penelitian Indah (2012), dengan judul pengaruh pengelolaan keuangan daerah dan sistem akuntansi keuangan daerah terhadap kinerja pemerintahan daerah pada DPKAD di pemerintahan kota bandung. Hasil penelitiannya menunjukkan bahwa pengelolaan keuangan daerah, sistem akuntansi keuangan daerah dan kinerja pemerintahan daerah bersama-sama memiliki pengaruh yang signifikan. Pengaruh pengelolaan keuangan daerah berdampak positif dan signifikan terhadap sistem akuntansi keuangan daerah dan kinerja pemerintahan daerah, yaitu $65,8 \%$.

Dengan demikian perbedaan penelitian ini dengan sebelumnya adalah
Sistem Akuntansi Keuangan Daerah menggunakan Permendagri No. 64 Tahun 2013, sedangkan penelitian sebelumnya menggunakan Kepmendagri No. 29 Tahun 2002. Obyek penelitian juga berbeda karena dilakukan di BPKAD kota padang.

Berdasarkan latar belakang masalah diatas, maka rumusan masalah dalam penelitian ini adalah; (1) Bagaimana pengaruh pengelolaan keuangan daerah terhadap kinerja pemerintahan daerah pada Badan Pengelolaan Keuangan dan Aset Daerah kota padang?; (2) Bagaimana pengaruh sistem akuntansi keuangan daerah terhadap kinerja pemerintahan daerah pada Badan Pengelolaan Keuangan dan Aset Daerah kota padang?; (3) Bagaimana pengaruh pengelolaan keuangan daerah, sistem akuntansi keuangan daerah terhadap kinerja pemerintahan daerah pada Badan Pengelolaan Keuangan dan Aset Daerah Kota Padang?

Akuntansi Manajemen Sektor Pubrik

Menurut Mardiasmo dalam bukunya (2009:6) Akuntansi manajemen sektor publik sebagai:

a. Akuntansi sebagai alat perencanaan organisasi Artinya perencanaan merupakan cara organisasi menetapkan tujuan dan sasaran organisasi, yang meliputi aktivitas yang sifatnya strategik, taktis dan melibatkan aspek operasional. Dalam hal perencanaan organisasi akuntansi manajemen berperan dalam pemberian informasi historis pada prospektif untuk memfasilitasi perencanaan.

b. Akuntansi sebagai alat pengendali organisasi Untuk menjamin agar strategi dapat mencapai tujuan organisasi dijalankan secara ekonomis, efisien dan efektif, maka diperlukan suatu sistem pengendalian yang efektif. Strategi pengendalian tiap organisasi berbeda-beda 
tergantung pada jenis dan karakteristik organisasi.

Kinerja Pemerintahan Daerah

Menurut Chabib (2011:3) kinerja adalah gambaran tingkat pencapaian pelaksanaan suatu kegiatan/ program/ kebijakan dalam mewujudkan sasaran, tujuan, misi dan visi organisasi yang tertuang dalam perumusan perencanaan strategis suatu organisasi.

Kinerja dari suatu pemerintah keberhasilan suatu kegiatan/program yang telah dilakukan untuk mencapai tujuan-tujuan pembangunan yang diwujudkan dalam bentuk hasil berupa peningkatan pelayanan kepada masyarakat. Kinerja pemerintah daerah tidak ditutupi dari masyarakat, tetapi harus diinformasikan karena masyarakat seabgai pemangku kepentingan mengenai tingkat pencapaian hasil, dikaitkan dengan misi dan visi organisasi. Melalui informasi tersebut, selanjutnya dapat diambil langkahlangkah atau tindakan koreksi yang diperlukan atas penetapan kegiatan/program utama, dan sekaligus pada saat yang bersamaan dijadikan umpan balik sebagai bahan untuk perencanaan.

Pengelolaan Keuangan Daerah

Peraturan Pemerintah Nomor 71 tahun 2010 juga dijelaskan bahwa yang dimaksud dengan Pengelolaan Keuangan Daerah adalah keseluruhan kegiatan yang meliputi perencanaan, pelaksanaan, penatausahaan pelaporan, pertanggungjawaban dan pengawasan keuangan daerah. Keuangan Daerah dikelola secara tertib, taat pada peraturan peruandang-undangan, efisien, ekonomis, efektif transparan dan bertanggung jawab dengan memperhatikan azas keadilan, kepatuhan, dan manfaat untuk masyarakat.

Sistem Akuntansi Keuangan Daerah
Menurut Rasdianto (2013:6) Sistem akuntansi keuangan daerah adalah sistem akuntansi yang meliputi proses pencatatan, penggolongan, penafsiran, peringkasan transaksi atau kejadian keuangan serta pelaporan keuangan dalam rangka pelaksanaan anggaran pendapatan dan belanja daerah (APBD).

Sistem akuntansi keuangan daerah diatur dalam Permendagri No. 64 Tahun 2013 Tentang Penerapan Standar Akuntansi Pemerintah Berbasis Berbasis Akrual Pada Pemerintah Daerah. Menurut Permendagri No. 64 Tahun 2013 tersebut, Sistem Akuntansi Pemerintah Daerah atau Sistem Akuntansi Keuangan Daerah merupakan rangkaian sistematik dari prosedur, penyelenggara, peralatan dan elemen lain untuk mewujudkan 19 fungsi akuntansi sejak analisis transaksi sampai dengan pelaporan keuangan di lingkungan organisasi pemerintah daerah.

\section{METODE PENELITIAN}

Jenis penelitian yang digunakan pada penelitian ini yaitu penelitian kausual, dengan metode kualitatif dan kuantitatif. Menurut Sugiyono (2014:37) "Hubungan kausal adalah hubungan yang bersifat sebab akibat".

Sumber data yang peneliti ambil dari penelitian ini adalah pada Badan Pengelolaan Keuangan dan Aset Daerah (BPKAD) Kota Padang yang berlokasi di Jl. Prof. M. Yamin, SH No. 70 Padang.

Definisi Operasional Variabel

Berdasarkan hubungan antara satu variabel dengan variabel lain, maka variabel dalam penelitian ini adalah sebagi berikut :

1. Variabel Bebas (Independent Variable) Menurut Sugiyono (2015) "variabel ini sering disebut sebagai variabel stimulus, predicator, antecendent. Variabel bebas adalah 
variabel yang mempengaruhi baik pengaruh positif maupun pengaruh negative bagi variabel dependen nantinya atau yang menjadi sebab perubahannya dan timbulnya variabel idependen (terikat)". Maka dalam penelitian ini yang menjadi variabelvariabel bebas (independent variable) dalam penelitian ini adalah Pengelolaan Keuangan Daerah (X1), Sistem Akuntansi Keuangan Daerah ( $\mathrm{X} 2$ ).

2. Variabel Terikat (Dependent variable) Menurut Sugiyono (2015) "variabel terikat sering disebut sebagai variabel output, kriteria, konsekuen. Variabel terikat merupakan variabel yang dipengaruhi atau yang menjadi akibat, karena adanya variabel bebas". Sesuai dengan masalah yang akan diteliti maka yang akan menjadi Variabel terikat dalam penelitian ini adalah Kinerja Pemerintahan Daerah (Y).

Populasi dan Sampel Penelitian

Populasi penelitian ini adalah seluruh pegawai yang bekerja pada Badan Pengelolaan Keuangan dan Aset Daerah di Kota Padang, dengan jumlah 83 orang pegawai, yang terdiri dari 66 orang pegawai negeri sipil dan 17 orang pegawai honor. Populasi yang ada ini, akan digunakan teknik kuesioner dalam pengumpulan data yang digunakan dalam penelitian.

Didalam penelitian ini menggunakan metode survey yaitu penelitian yang digunakan untuk menjelaskan hubungan kausal dan pengujian hipotesis. Dalam penelitian survey ini, penulis melakukan penelitian langsung pada BPKAD kota padang untuk memperoleh data yang berhubungan dengan penelitian ini.

Metode Pengumpulan Data

Sumber data yang digunakan peneliti mengenai pengaruh pengelolaan keuangan daerah dan sistem akuntansi keuangan daerah terhadap kinerja pemerintahan daerah adalah data primer dan sekunder.

Teknik Pengumpulan Data

Pengumpulan data yang

dilakukan dalam penelitian ini diperoleh dengan teknik-teknik sebagai berikut; (1) .Penelitian lapangan (Field Reseach); (a) Metode Pengamatan, dalam penulisan laporan ini, penulis mengadakan pengamatan langsung pada Badan Pengelolaan Keuangan dan Aset Daerah Pemerintah Kota Padang; (b). Wawancara (interview), dalam teknik wawancara pada penelitian ini yang akan diwawancara merupakan Pegawai Negeri Sipil yang bekerja di BPKAD yaitu Pegawai yang memiliki jabatan sebagai kepala, sekretariat, sub bagian, bidang, dan sub bidang; (c). Kuesioner; (d). Dokumen. (2). Peneliti kepustakaan, penelitian ini dilakukan melalui studi kepustakaan atau studi literatur dengan cara mempelajari, meneliti, mengkaji serta menelaah literatur berupa buku-buku (text book), peraturan perundang-undangan, majalah, suratkabar, artikel, situsweb dan penelitian-penelitian sebelumnya yang memiliki hubungan dengan masalah yang diteliti. Studi kepustakaan ini bertujuan untuk memperoleh sebanyak mungkin teori yang diharapkan akan dapat menunjang data yang dikumpulkan dan pengolahannya lebih lanjut dalam penelitian ini.

Metode Analisis Data

Ada beberapa uji yang digunakan dalam metode analisis data, sebagai berikut:

\section{Uji Validitas}

Menurut Sugiyono (2014:267) "Validitas adalah derajat ketepatan antara data yang terjadi pada objek penelitian / data yang sesungguhnya terjadi dengan data yang dapat dilaporkan oleh peneliti".

"Penelitian ini menguji validitas data melalui metode triangulasi sumber, yaitu pengecekan data yang 
telah diperoleh kepada sumber / informan yang berbeda-beda dengan tujuan memperoleh pandangan berbeda dari berbagai sumber dengan menggunakan satu metode yang sama untuk mengurangi bisa atau kesalahan pada waktu pengumpulan dan analisis data"(Sugiyono, 2013:273).

Pengujian dilakukan secara statistik, yang dapat dilakukan secara manual atau dukungan komputer, misalnya melaui bantuan paket komputer SPSS. Uji validitas ini dilakukan dengan membandingkan secara terhitung dan $r$ hitung dan $r$ tabel melalui tahapan analisis sebagai berikut :

$$
\mathbf{r}=\frac{\mathbf{n}\left(\sum \mathrm{XY}\right)-\left(\sum \mathrm{X} \sum \mathrm{Y}\right)}{\sqrt{\left\{\mathbf{n X 2}-\left(\sum \mathbf{x}\right) 2\right\}\left\{\mathbf{n} \sum \mathbf{y} 2-\left(\sum \mathbf{y}\right) \mathbf{y}^{2}\right.}}
$$

\section{Uji Realiabilitas}

"Reliabilitas adalah derajat stabilitas dan konsistensi data yaitu jika penelitian direplikasi pada kondisi yang berbeda tetapi memberikan hasil yang sama" (Sugiyono, 2013:268). Uji reliabilitas data menurut (Sugiyono, 2014) "dilakukan dengan cara audit data pada auditor dan para ahli untuk menganalisis seluruh kegiatan penelitian yang dilakukan peneliti”.

\section{Rancangan Analisis dan Pengujian Hipotesis}

Peneliti melakukan analisa terhadap data yang telah diuraikan dengan menggunakan metode kualitatif dan metode kuantitatif.

\section{Analisis kualitatif}

$$
\text { Menurut Sugiyono }
$$

"Metode kualitatif yaitu metode penelitian yang berlandaskan pada filsafat postpositivisme/ enterpretif, digunakan untuk meneliti pada kondisi obyek yang alamiah, (sebagai lawannya adalah eksperimen) dimana peneliti sebagai instrumen kunci, teknik pengumpulan data dilakukan secara trianggulasi (gabungan), analisis data bersifat induktif/ kualitatif, dan hasil penelitian kualitatif lebih menekankan makna dari generalisasi".

2. Analisis kuantitatif

Menurut Sugiyono (2015) "Metode kuantitatif adalah metode penelitian yang berlandaskan pada filsafat positivism, digunakan untuk meneliti pada populasi atau sampel tertentu, pengumpulan data menggunakan instrumen peneliti, analisis data bersifat kuantitatif/ statistik, dengan tujuan untuk menguji hipotesis yang telah ditetapkan".

Dimana variabel X1 (pengelolaan keuangan daerah) dan X2 (sistem akuntansi keuangan daerah) dipasangkan dengan data variabel $\mathrm{Y}$ (kinerja pemerintahan daerah) yang dikumpulkan melalui kuesioner masih memiliki skala ordinal, maka sebelum diolah data ordinal terlebih dahulu dikonversi menjadi data interval menggunakan Methode Succesive Internal (MSI). Hasil data yang telah dikonversi tersebut selanjutnya diolah menggunakan analisis berikut:

a. Uji Asumsi Klasik

Dalam penelitian ini untuk mengolah data dari hasil penelitian ini dengan menggunakan Analisis Inferensial (kuantitatif). Dimana dalam analisis tersebut dengan menggunakan paket program SPSS. Analisis data dilakukan dengan bantuan Metode Regresi Linear Berganda, tetapi sebelum melakukan analisis regresi linear berganda digunakan uji asumsi klasik yang meliputi uji normalitas, uji multikolinearitas dan uji heterokesdastisitas.

b. Analisis Regresi Linear Berganda

Analisis Regresi Linier Berganda bertujuan untuk mengetahui pengaruh pengelolaan keuangan daerah dan sistem akuntansi keuangan daerah terhadap kinerja 
pemerintahan daerah. Persamaan regresi yang diharapkan dalam penelitian ini adalah:

\section{$Y=a 0+b 1 X 1+b 2 X 2+e$}

\section{c. Analisis Korelasi}

"Analisis ini digunakan untuk mengetahui kekuatan hubungan antara variabel $\mathrm{X}$ dengan Variabel $\mathrm{Y}$ secara bersamaan. Perhitungan analisis koefisien korelasi dengan rumus pearson" (Sugiyono, 2009:183), yaitu:

$$
r=\frac{\eta(\Sigma \mathbf{X i Y i})-(\Sigma \mathbf{X i})(\Sigma \mathbf{Y i})}{\sqrt{\left\{\boldsymbol{\eta}\left(\Sigma \mathbf{X i}^{2}\right)-\left(\Sigma \mathbf{X i}^{2}\right)\right\}\left\{\boldsymbol{\eta}\left(\Sigma \mathbf{Y i}^{2}\right)-(\Sigma \mathbf{Y i})^{2}\right\}}}
$$

\section{d. Analisis Determinasi}

Persentase peranan semua variable bebas atas nilai variable bebas ditunjukan oleh besarnya koefisien determinasi $\left(\mathrm{R}^{2}\right)$. semakin besar nilainya maka menunjukkan bahwa persamaan regresi yang dihasilkan baik untuk mengestimasi variable terikat.

Hasil koefisien determinasi ini dapat dilihat dari perhitungan dengan Microsoft/SPSS atau secara manual didapat dari $\mathrm{R}^{2}=\mathrm{SSreg} / \mathrm{SStot}$.

\section{Uji Hipotesis}

Yaitu untuk mengetahui tingkat signifikan dari pengaruh variabel independen secara keseluruhan terhadap variabel dependen. Uji hipotesis merupakan suatu perumusan sementara mengenai suatu hal yang dibuat untuk menjelaskan hal itu dan juga dapat mengarahkan penyediaan selanjutnya. Dalam penelitian ini dilakukan pengujian variabel bebas terhadap variabel terikat dengan mneggunakan uji - T dan uji-F.

\section{HASIL DAN PEMBAHASAN}

Badan Pengelola Keuangan dan Aset (BPKAD) Kota Padang merupakan Badan/Satuan Kerja Perangkat Daerah (SKPD) yang dibentuk berdasarkan Peraturan Daerah Nomor 6 Tahun 2015.
Sebelumnya BPKA Kota Padang merupakan SKPD yang bernama Dinas Pengelolaan Keuangan dan Aset (DPKA) Kota Padang, namun seiring dengan kebutuhan peningkatan kinerja pemerintah dan organisasi, maka DPKA Kota Padang dibagi menjadi dua SKPD yakni BPKAD Kota Padang yang dibentuk dengan Perda Nomor 6 Tahun 2015 dan Dinas Pendapatan Daerah (Dipenda) Kota Padang yang dibentuk dengan Peraturan Daerah Nomor 5 Tahun 2015. BPKA berganti nomenklatur dari BPKA menjadi BPKAD (Badan Pengelolaan Keuangan dan Aset Daerah) Kota Padang setelah terbit Peraturan Pemerintah Nomor 18 Tahun 2016 tentang Perangkat Daerah dan Peraturan Walikota Padang Nomor 89 Tahun 2016 tentang Kedudukan, Susunan Organisasi dan Tata Kerja Badan Pengelolaan Keuangan dan Aset Daerah.

Uji Instrumen Penelitian

\section{Uji Validitas}

Hasil Uji Validitas menunjukkan bahwa korelasi antara masing-masing indikator terhadap total skor konstruk dari setiap variabel menunjukkan hasil yang signifikan, dan menunjukkan bahwa $\mathrm{r}$ hitung $>\mathrm{r}$ tabel dimana r-tabel bernilai 0.30 . Dengan demikian indikator atau kuesioner yang digunakan oleh masing-masing variabel dinyatakan valid untuk digunakan sebagai alat ukur variable.

2. Uji Reliabilitas

Hasil uji reliabilitas menunjukkan bahwa semua variabel mempunyai koefisien Alpha yang cukup besar yaitu diatas 0,60 dengan nilai masing-masing valiabel $\mathrm{Y}, \mathrm{X} 1$, dan X2 sebesar 0,864, 0,883 dan 0,880 , sehingga dapat dikatakan semua konsep pengukur masingmasing variabel dari kuesioner adalah reliabel sehingga untuk selanjutnya item-item pada masing-masing konsep 
variabel tersebut layak digunakan sebagai alat ukur. dan semua item pertanyaan bisa dilakukan untuk pengujian selanjutnya.

Uji Asumsi Klasik

1. Uji Normalitas

Dalam penelitian ini uji normalitas adalah sebagai berikut :

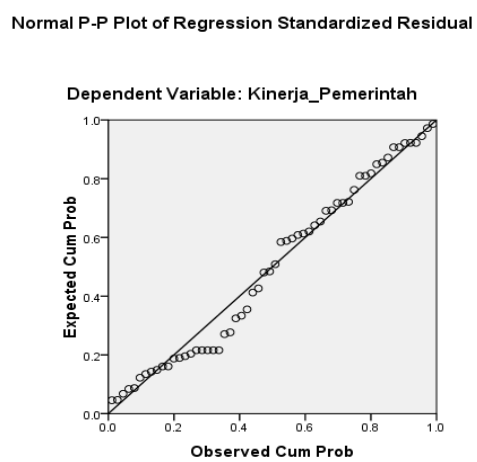

\section{Gambar 1. Uji Normalitas}

Berdasarkan grafik P-Plot di atas, data dalam penelitian ini terdistribusi normal karena persebaran data mengikuti garis diagonal seperti yang terlihat pada gambar di atas.

2. Uji Heteroskedastisitas

Dalam penelitian ini uji heteroskedastisitas adalah sebagai berikut:

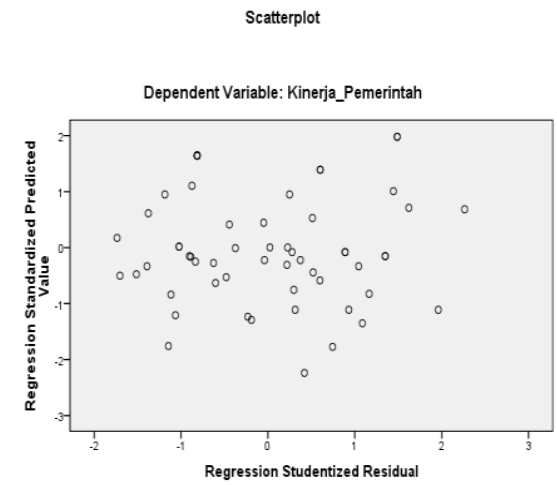

Sumber: Lampiran output SPSS

Gambar 2

Uji Heteroskedastisitas

$\begin{array}{ccr}\text { Dari } & \text { gambar diatas } & \text { dapat } \\ \text { diketahui } & \text { tidak } & \text { terjadi }\end{array}$ heteroskedastisitas sebab tidak ada pola yang jelas serta titik-titik menyebar di atas dan di bawah angka 0 pada sumbu
Y. sehingga dapat dikatakan uji asumsi klasik terpenuhi.

\section{Uji Multikolinieritas}

Berdasarkan hasil uji multikolinieritas didapatkan bahwa nilai semua nilai $\mathrm{VIF}<10$ yaitu sebesar 1,655 ini berarti tidak terjadi multikolonieritas. Dan menyimpulkan bahwa uji asumsi klasik terpenuhi.

\section{Pengujian Hipotesis}

1. Analisis regresi berganda

Hasil analisis regresi berganda dapat diketahui persamaan regresi yang terbentuk adalah;

a. Dari persamaan regresi berganda diatas terlihat bahwa nilai konstanta sebesar 2.385 menunjukan bahwa tanpa adapun variabel bebas yaitu Pengelolaan Keuangan Daerah dan Sistem Akuntansi Keuangan Daerah terhadap Kinerja Pemerintah Daerah sebesar 2.385 .

b. Nilai koefisien Pengelolaan Keuangan Daerah (X1) yakni -0.236 Hal ini menunjukan bahwa apabila Pengelolaan Keuangan Daerahmeningkat sebesar satusatuan maka terhadap Kinerja Pemerintah Daerah (Y) akan menurun sebesar 0.236 atau $23.6 \%$ dengan asumsi variabel Sistem Akuntansi Keuangan Daerah tetap.

c. Nilai koefisien Sistem Akuntansi Keuangan Daerah (X2) yakni 0.612 Hal ini menunjukan bahwa apabila Sistem Akuntansi Keuangan Daerah meningkat sebesar satu-satuan maka terhadap Kinerja Pemerintah Daerah (Y) akan meningkat sebesar 0.612 atau $61.2 \%$ dengan asumsi variabel Pengelolaan Keuangan Daerah tetap.

\section{Uji t hitung}

Berdasarkan hasil uji $t$ dapat diinterpretasikan sebagai berikut:

a. Hasil pengujian hipotesis Pengelolaan Keuangan Daerah menunjukkan nilai t hitung sebesar 1.394 dengan taraf signifikansi 
0.169. Taraf signifikansi tersebut lebih besar dari 0.05.Dengan demikian dapat berarti bahwa hipotesis H1 Pengelolaan Keuangan Daerah tidak mempunyai pengaruh signifikan terhadap Kinerja Pemerintah Daerah.

b. Hasil pengujian hipotesis Sistem Akuntansi Keuangan Daerahmenunjukkan nilai $\mathrm{t}$ hitung sebesar 4.322 dengan taraf signifikansi 0.000 . Taraf signifikansi tersebut lebih kecildari 0.05. Dengan demikian dapat berarti bahwa hipotesis H2 Sistem Akuntansi Keuangan Daerahmempunyai pengaruh signifikan terhadap Kinerja Pemerintah Daerah.

3. Uji F hitung

Berdasarkan Hasil pengujian hipotesis Pengelolaan Keuangan Daerah dan Sistem Akuntansi Keuangan Daerah terhadap Kinerja Pemerintah Daerah menunjukkan nilai f hitung sebesar 10.794 dengan taraf signifikansi 0.000 . Taraf signifikansi tersebut lebih kecil dari 0.05. Dengan demikian dapat berarti bahwa hipotesis H3 Pengelolaan Keuangan Daerah dan Sistem Akuntansi Keuangan Daerah mempunyai pengaruh signifikan terhadap Kinerja Pemerintah Daerah.

\section{Koefisien Determinan}

Hasil uji koefisien determinan menunjukkan besar pengaruhnya Pengelolaan Keuangan Daerah dan Sistem Akuntansi Keuangan Daerah terhadap Kinerja Pemerintah Daerah adalah sebesar 0.256 atau $25.6 \%$. Hal ini menunjukkan bahwa pengaruhnya Pengelolaan Keuangan Daerah dan Sistem Akuntansi Keuangan Daerah terhadap Kinerja Pemerintah Daerah sebesar $25.6 \%$, sedangkan sisanya sebesar $74.4 \%$ dijelaskan oleh faktorfaktor lain yang tidak digunakan dalam model regresi penelitian ini.

\section{Pembahasan}

\section{Pengaruh Pengelolaan Keuangan Daerah terhadap Kinerja Pemerintah Daerah.}

\section{Hasil pengujian hipotesis} Pengelolaan Keuangan Daerah menunjukkan nilai $\mathrm{t}$ hitung sebesar 1.394 dengan taraf signifikansi 0.169 . Taraf signifikansi tersebut lebih besar dari 0.05.Dengan demikian dapat berarti bahwa hipotesis H1 Pengelolaan Keuangan Daerah tidak mempunyai pengaruh signifikan terhadap Kinerja Pemerintah Daerah. Hal ini berarti peningkatan atau penurunan Pengelolaan Keuangan Daerah yang dilakukan Badan Pengelolaan Keuangan Dan Aset Daerah (BPKAD) Kota Padang saat ini tidak akan berdampak pada Kinerja Pemerintah Daerah seperti anggaran disusun dengan menggunakan pendekatan kinerja, Pemerintah daerah menyampaikan rancangan APBD kepada DPRD untuk mendapatkan persetujuan, setiap perangkat daerah yang bertugas memungut atau menerima pendapatan daerah wajib melaksanakan intensifikasi pemungutan pendapatan daerah, pendapatan daerah disetor sepenuhnya tepat waktu ke kas daerah, sesuai dengan ketentuan peraturan perundang-undangan yang berlaku, Tindakan yang mengakibatkan pengeluaran atas beban APBD tidak dapat dilakukan sebelum ditetapkan di dalam peraturan daerah tentang APBD, Setiap pengeluaran atas beban APBD diterbitkan Surat Keputusan Otorisasi oleh pejabat yang berwenang, pembebanan atas APBD harus dilengkapi dengan bukti-bukti yang lengkap dan sah, laporan keuangan disusun untuk menyediakan informasi yang relevan mengenai posisi keuangan dan seluruh transaksi, laporan keuangan harus dapat dimengerti dan disajikan sesuai 
dengan standar akuntansi yang diterima umum, setiap pejabat pengelolaan keuangan daerah menyusun laporan pertanggungjawaban keuangan secara periodik dan pengawasan atas pelaksanaan APBD dilakukan oleh DPR.

Hasil penelitian ini tidak sejalan dengan penelitian Indah (2012) yang melakukan penelitian di Kota Bandung menunjukkan bahwa, pengelolaan keuangan daerah di kota bandung berpengaruh signifikan positif terhadap kinerja pemerintah daerah tersebut dan Hidayat (2015) yang melakukan penelitian di kabupaten Padang Pariaman juga menunjukkan bahwa, pengelolaan keuangan daerah kabupaten padang pariaman berpengaruh signifikan positif terhadap kinerja pemerintah daerah tersebut.

Hal ini disebabkan banyak pengelola keuangan pada pemerintah Kota Padang yang masih kurang memahami dengan perubahan aturan dalam pengelolaan keuangan, perencanaan yang belum dilaksanakan dengan baik. Perubahan aturan dengan terbitnya Permendagri 64 tahun 2013 mewajibkan Pemerintah Kota Padang menggunakan akuntansi berbasis akrual sehingga perlu dilakukan sosialisasi/bimbingan teknis untuk menghindari kesalahan-kesalahan akibat dari perubahan aturan yang harus dipahami agar para pengelola keuangan mampu melakukan perbaikan yang menyeluruh disamping sikap kehati-hatian dari pengelola keuangan menjadi beban tersendiri dalam mengelola keuangan.

Hal ini menjadi penyebab kurangnya pemahaman pengelolaan dengan benar, masih adanya rangkap tugas yang di laksanakan oleh bendahara pengeluaran, atau kepada operator SIMDA, sehingga tugas seorang PPK untuk memeriksa kebenaran dari setiap transaksi keuangan di SKPD tidak berfungsi sebagaimana mestinya perubahan yang begitu cepat pada aturan keuangan yang membuat para pengelola keuangan sulit memahaminya.

Untuk mengurangi permasalahan ini pemerintah daerah kota padang harus meningkatkan kapasitas sumber daya manusia yang mengelola keuangan lewatbimbingan teknis dan pelatihan akuntansi lainnya.

\section{Pengaruh Sistem Akuntansi Keuangan Daerah terhadap Kinerja Pemerintah Daerah.}

Hasil pengujian hipotesis Sistem Akuntansi Keuangan Daerah menunjukkan nilai $\mathrm{t}$ hitung sebesar 4.322 dengan taraf signifikansi 0.000 . Taraf signifikansi tersebut lebih kecil dari 0.05. Dengan demikian dapat berarti bahwa hipotesis H2 Sistem Akuntansi Keuangan Daerahmempunyai pengaruh signifikan terhadap Kinerja Pemerintah Daerah. Hal ini berarti peningkatan Sistem Akuntansi Keuangan Daerah yang dilakukan Badan Pengelolaan Keuangan Dan Aset Daerah (BPKAD) Kota Padang akan berdampak pada Kinerja Pemerintah Daerah seperti Sistem pencatatan keuangan yang dilakukan sudah sesuai dengan standar dan prosedur yang telah ditetapkan, pencatatan keuangan yang dilakukan selama ini sudah efektif, evaluasi dan pengawasan terhadap pencatatan keuangan sering dilakukan, sering terjadi kesalahan, kecurangan atau penyimpangan dalam pencatatan keuangan, pencatatan keuangan yang dilakukan telah relevan dengan fakta atau keadaan keuangan yang ada, identifikasi atau pengklasifikasian perlu dilakukan dalam pelaksanaan sistem akuntans keuangan daerah, 
semua bidang akuntansi keuangan dan transaksi ekonomi perlu dilakukan identifikasi atau pengklasifikasian, pelaporan yang dilakukan sudah sesuai dengan fakta dan keadaan keuangan yang sesungguhnya, sering terjadi kesalahan atau penyimpangan dalam pelaporan keuangan dan pelaporan keuangan yang dilakukan sudah memberikan dampak yang positif atau manfaat bagi instansi.

Hasil penelitian ini sama dengan penelitian yang dilakukan oleh Hidayat (2015), bahwa sistem akuntansi keuangan daerah berpengaruh signifikan positif terhadap kinerja pemerintahan daerah.

\section{Pengaruh Pengelolaan Keuangan} DaerahdanSistem Akuntansi Keuangan Daerah terhadap Kinerja Pemerintah Daerah.

Berdasarkan Hasil pengujian hipotesis Pengelolaan Keuangan Daerah dan Sistem Akuntansi Keuangan Daerah terhadap Kinerja Pemerintah Daerah menunjukkan nilai f hitung sebesar 10.794 dengan taraf signifikansi 0.000 . Taraf signifikansi tersebut lebih kecil dari 0.05. Dengan demikian dapat berarti bahwa hipotesis H3 Pengelolaan Keuangan Daerah dan Sistem Akuntansi Keuangan Daerah mempunyai pengaruh signifikan terhadap Kinerja Pemerintah Daerah. Dari tabel diatas menunjukkan besar pengaruhnya Pengelolaan Keuangan Daerah dan Sistem Akuntansi Keuangan Daerah terhadap Kinerja Pemerintah Daerah adalah sebesar 0.256 atau $25.6 \%$. Hal ini menunjukkan bahwa pengaruhnya Pengelolaan Keuangan Daerah dan Sistem Akuntansi Keuangan Daerah terhadap Kinerja Pemerintah Daerah sebesar $25.6 \%$, sedangkan sisanya sebesar $74.4 \%$ dijelaskan oleh faktorfaktor lain yang tidak digunakan dalam model regresi penelitian ini.

Keberhasilan sinerja
pemerintahan suatu daerah dapat
dinilai dari meningkatnya
pembangunan baik di bidang ekonomi,
politik, sosial maupun budaya. Masyarakat luas menilai keberhasilan pembangunan di bidang ekonomi terwujud dalam pembangunan infrastruktur. Dalam pembangunan infastruktur takkan berhasil tanpa adanya pengelolaan keuangan yang baik oleh pemerintah dalam mengelola APBD. Dengan terealisasinya APBD pemerintah yang sejalan dengan terlaksananya program-program pemerintahan yang mendukung kepentingan rakyat, maka telah mejamin kinerja pemeritah daerah tersebut makin baik pula.

Hal ini menunjukkan bahwa kinerja para pegawai dilingkungan Pemerintah Daerah Kota Padang memiliki hasil yang baik walaupun beberapa hal belum tercapai seperti Produk anggaran sebagai hasil kerja yang dijalankan oleh unit kerja belum dapat dirasakan secara merata oleh masyarakat pencapaian realisasi anggaran tiap tahun tidak mencapai target, kurangnya pemahaman aparat terhadap penyusunan anggaran.Sehingga dapat disimpulkan bahwa Pengelolaan Keuangan Daerah dan Sistem Akuntansi Keuangan Daerah merupakan hal yang sangat penting dalam menunjang baiknya Kinerja Pemerintah Daerah yang ada dilingkungan Pemerintah Daerah kota Padang.

Hasil penelitian ini sama dengan penelitian yang dilakukan oleh Indah (2012), bahwa pengelolaan keuangan daerah dan sistem akuntansi keuangan daerah memberikan pengaruh yang signifikan terhadap kinerja pemerintahan daerah. 


\section{SIMPULAN}

Berdasarkan hasil penelitian dan pembahasan pada bab sebelumnya maka dapat diambil kesimpulan adalah sebagai berikut:

1. Hasil pengujian hipotesisPengelolaan Keuangan Daerah menunjukkan nilai $\mathrm{t}$ hitung sebesar 1.394 dengan taraf signifikansi 0.169. Taraf signifikansi tersebut lebih besar dari 0.05. Dengan demikian dapat berarti bahwa hipotesis H1Pengelolaan Keuangan Daerah tidak mempunyai pengaruh signifikan terhadap Kinerja Pemerintah Daerah.

2. Hasil pengujian hipotesis Sistem Akuntansi Keuangan Daerahmenunjukkan nilai $\mathrm{t}$ hitung sebesar 4.322 dengan taraf signifikansi 0.000. Taraf signifikansi tersebut lebih kecildari 0.05.Dengan demikian dapat berarti bahwa hipotesis $\mathrm{H} 2$ Sistem Akuntansi Keuangan Daerahmempunyai pengaruh signifikan terhadap Kinerja Pemerintah Daerah.

3. Berdasarkan tabel 4.9 Hasil pengujian hipotesis Pengelolaan Keuangan Daerah dan Sistem Akuntansi Keuangan Daerah terhadap Kinerja Pemerintah Daerah menunjukkan nilai $\mathrm{f}$ hitung sebesar 10.794 dengan taraf signifikansi 0.000. Taraf signifikansi tersebut lebih kecil dari 0.05. Dengan demikian dapat berarti bahwa hipotesis H3 Pengelolaan Keuangan Daerah dan Sistem Akuntansi Keuangan Daerah mempunyai pengaruh signifikan terhadap Kinerja Pemerintah Daerah. Dari tabel diatas menunjukkan besar pengaruhnya Pengelolaan Keuangan Daerah dan Sistem Akuntansi Keuangan Daerah terhadap Kinerja Pemerintah Daerah adalah sebesar 0.256 atau $25.6 \%$. Hal ini menunjukkan bahwa pengaruhnya Pengelolaan Keuangan Daerah dan Sistem Akuntansi Keuangan Daerah terhadap Kinerja Pemerintah Daerah sebesar $25.6 \%$, sedangkan sisanya sebesar $74.4 \%$ dijelaskan oleh faktor-faktor lain yang tidak digunakan dalam model regresi penelitian ini.

Berdasarkan perumusan masalah dan telah dibahas pada bab sebelumnya maka peneliti menyarankan adalah sebagai berikut :

1. Dalam penelitian ini alat ukur yang digunakan untuk mengetahui pengaruh Kinerja Pemerintah Daerah adalah Pengelolaan Keuangan Daerah dan Sistem Akuntansi Keuangan Daerah, padahal masih banyak faktor lain yang mempengaruhi Kinerja Pemerintah Daerah, untuk penelitian yang akan datang diharapkan akan meneliti yang lebih luas lagi.

2. Selain itu, penelitian ini perlu di uji dengan responden berbeda dan memperbesar jumlah sampel penelitian.

3. Kepada pihak yang terkait dengan pengelolaan keuangan daerah di pemerintah kota padang agar lebih meningkatkan prinsip-prinsip pengelolaan keuangan agar lebih efektif dan efisien.

4. Kepada pemerintah kota padang agar lebih meningkatkan pemahaman karyawan terhadap sistem akuntansi keuangan daerah, salah satunya dengan cara adanya pengrahan dari kepala bagian kepada karyawan pelaksanaan sistem akuntansi daerah terutama dalam hal pencatatannya dengan lebih menekankan lagi penggunaan terhadap sistem pencatatan yang lebih baik dan lebih mudah serta transparan agar dapat berjalan dengan baik dan optimal.

5. Agar seluruh elemen kinerja pemerintah lebih baik diharapakan "Indikator Dampak" yang meliputi tentang kesejahteraan masyarakat dan pendapatan masyarakat lebih di tingkatkan oleh pemerintah kota padang. 


\section{DAFTAR PUSTAKA}

Anitasari. 2016. Pengaruh Sistem Keuangan Daerah dan Anggaran Berbasis

TerhadapKinerjaPemerintahan Daerah (Survei pada Satuan Kerja Perangkat Daerah KotaCimahi). Jurnal.Fakultas Ekonomi dan Bisnis Universitas Komputer Indonesia.

Annisa, Vivid. 2017. Pengaruh Sistem Akuntansi Daerah, Pengelolaan Keuangan Daerah dan Good Governance Terhadap kinerja Pemerintahan Daerah (Studi Pada Satuan Kerja Perangkat Daerah Kota Pekanbaru). Jurnal. Fakultas Ekonomi-Universitas

Riau,Pekanbaru, Indonesia.

Bastian, Indra. 2010. Akuntansi Sektor Publik Suatu Pengantar. Edisi Ketiga. Jakarta Erlangga.

Chabib Sholeh. 2009. Pengelolaan Keuangan dan Aset Daerah. Bandung: Focus Media.

Hidayat, Rahmat. 2015. Pengaruh Pengelolaan Keuangan Daerah dan Sistem Akuntansi Daerah Terhadap Kinerja Pemerintahan Daerah (Studi Empiris pada Satuan Kerja Perangkat Daerah di Kabupaten Padang Pariaman). Skripsi. Fakultas ekonomi Universitas Negeri Padang.

https://www.harianhaluan.com/amp/deta il/40212,Senin/17/12/2018,11:40 WIB.

Indah, Ade. 2012. Pengaruh Pengelolaan Keuangan Daerah dan Sistem Akuntansi DaerahTerhadap Kinerja Pemerintahan Daerah (Studi pada Dinas Pengelolaan Keuangan danAset Daerah Di Pemerintahan Kota Bandung). Skripsi. Fakultas EkonomiUniversitas Komputer Indonesia.

Jauharusaniah, dkk. 2015. Pengaruh Pengelolaan Keuangan Daerah dan Partisipasi Penyusunan Anggaran
Terhadap Kinerja Pemerintahan

Daerah Kota Tanjungpinang.

Jurnal. Fakultas EkonomiUniversitas Maritim Raja Ali Haji Tanjungpinang.

Mahsun, Mohamad. 2012. Pengukuran Kinerja Sektor Publik. Yogyakakarta: BPFE.

Mardiosmo. 2009. Akuntansi Sektor publik. Yogyakarta. Andi.

Putra, Nopriansyah, dkk. 2016. Pengaruh Pengelolaan Keuangan Daerah, Akuntabilitas dan Transparansi Terhadap Kinerja Pemerintahan Daerah Dengan Pengawasan Sebagai Variabel Moderating pada Provinsi Sumatera Utara. Jurnal. Fakultas Ekonomi dan BisnisUniversitas Sumatera Utara.

Permendagri No. 64 Tahun 2013 tentang Sistem akuntansi Keuangan Daerah.

Permendagri No. 71 Tahun 2010 tentang Pengelolaan Keuangan Dearah.

Primadona Almanda. 2013. Pengaruh Pengawasan Intern dan pengelolaan Keuangan DaerahTerhadap Kinerja Pemerintahan Daerah.

Rohman, Abdul. 2009. Pengaruh Implementasi Sistem Akuntansi, Pengelolaan Keungan Daerah Terhadap Fungsi Pengawasan dan Kinerja Pemerintahan Daerah. Jurnal Akuntansi dan Bisnis vol 9 No. 1:21-32. (16 februari 2011).

Sugiyono. 2014. Metode Penelitian Kuantitatif Kualitatif dan R\&D. Alfabeta. Bandung.

Sugiyono. 2015. Metode Penelitian Manajemen. Alfabeta. Bandung. 